\title{
前腕筋活動電位の表面伝導解析*
}

\author{
中島康 博*1, 吉成 哲*1, 但野 茂*2
}

\section{Surface Conduction Analysis of EMG Signal from Forearm Muscles}

\author{
Yasuhiro NAKAJIMA*3, Satoshi YOSHINARI and Shigeru TADANO \\ ${ }^{* 3}$ Hokkaido Industrial Research Institute, \\ Kita 19 Nishi 11, Kita-ku, Sapporo-shi, Hokkaido, 060-0819 Japan
}

\begin{abstract}
Determining muscle forces of the finger during heavy work is important for an understanding and prevention of tenosynovitis. Electromyography is one index of muscle activity. Measurements by surface electromyography ( $\mathrm{SEMG}$ ) are noninvasive and simple to apply to obtain signals of muscle action potentials. The sEMG potentials of muscles near the electrode are superimposed. To identify the muscle activities from SEMG measurements, it is necessary first to analyze the characteristics of sEMG conduction in the forearm. This paper develops a conduction model of the forearm that incorporates the muscles and the radius and ulna bones. sEMG distributions were analyzed using the finite element method. The root mean square (RMS) values of sEMG values and the power exponent of attenuation in relation to the length between the electrode and the source of muscle action potential were estimated in this work. Further, the positions of the muscle action potential were reverse-estimated using the RMS values and the power exponent of attenuation. As a result, the peak potential position of the sEMG distributions was distorted at a circumferential angle around the longitudinal axis of the model up to a maximum of $48^{\circ}$. The power exponent of attenuation was found to increase monotonically with increases in the inter-electrode distance (IED) of the surface electrode pair. The errors in the estimated positions of muscle action potential increased with decreases in the distance between the source of muscle action potential and the radius and ulna bones.
\end{abstract}

Key Words: Finger, Forearm, Muscle Fibre, Surface Electromyography (sEMG), Conductive Model, Reverse-Estimation, Muscle and Skeleton, Computer Aided Analysis, Biomechanics

\section{1. 緒言}

人の手指は，精緻な作業から重作業まで様々な動作 が実現できるが、関節や筋に過度の負荷がかかること で腱鞘炎や関節炎等が発症しやすい，そのため，筋電 計や計算モデル等を用いて作業時の手指負荷を推定し， 傷害防止のための研究が行われている. 近年では，針 筋電計で測定された筋活動度を計算モデルに入力して 筋力を推定する手法もある. しかし，この手法は筋力 推定に有効だが, 針電極を筋に直接挿入するため被験 者の苦痛を伴い，また使用には医師の指示が必要など 計測上の制約が多い，簡便な表面筋電計により手指筋 の負荷が推定されることが望ましい.

表面筋電計は皮膚表面に貼り付けた表面電極を用

\footnotetext{
* 原稿受付 2008 年 8 月 14 日.

*1 正員, 北海道立工業試験場 (率060-0819 札幌沛北区北 19 条 西 11).

*2 正員, フェロー, 北海道大学大学院工学研究科.

E-mail : nakajima@hokkaido-iri.go.jp
}

いて，筋活動により生じた筋電位を測定する．前啘部 では図 1 に示すように 19 本の筋が密集している(1).表 面筋電計では内部のあらゆる筋活動の筋電位が同時に 重畳して測定されてしまうため, 各筋の筋活動度を個 別に特定する必要がある.

そのため, Roeleveld ら ${ }^{(2)(5)}$ はスキャニング筋電図法 を開発し，筋内部の活動とその伝導特性について明ら かにした．また，上腕の円周上に表面電極を配置し， 上腕二頭筋の運動単位の深さと強度を解析した。 Kleine $ら^{(6)(8)}$ は, 高密度 2 次元アレイ電極から得られた 筋電図を，空間フィルタを用いた解析法により僧帽筋 や総指伸筋などの筋活動電位の運動単位ごとへの分離

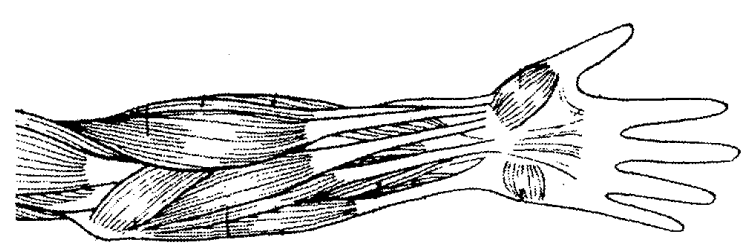

Fig. 1 Muscle structures of forearm and hand ${ }^{(1)}$ 
や位置推定を試みた．前川・松浦ら ${ }^{(9)}(10)$ は，前腕に配 置した 16 チャンネルの2次元アレイ電極を用いて測 定された表面筋電国から，ブラインドデコンボリュー ション法により前腕笳群の運動単位ごとの筋活動度を 求めた．斎藤ら ${ }^{(11)(14)}$ は，影像法を用いた表面筋電図逆 解析により, 上腕一頭筋の運動単位の位置やサイズを 推定したししし、これらの方法は運動単位の位置推 定に有効だが，多数の運動単位が動員されるような筋 活動時に，各筋の筋活動度を個別推定することは難し い.

Vigouroux $ら^{(15)(16)}$ は，針筋電図により総指伸筋，浅 指屈筋，深指屈筋の筋活動を実測し，筋骨格モデルに よる最適化手法と組み合わせて等尺收縮時における中 指腱張力を求めた，但野 (17) $^{(17)}$ ，示指の 3 次元指関節 の筋骨格モデルを構築し，逐次 2 次計画法を用いて外 力作用時の示指関連筋の筋力を解析した.これらは， 計算精度を上げるため筋活動量をモデルに入力してい るが，針筋電計を用いることから被験者の苦痛を伴う など計測上の制約がある.

本研究では，表面筋電計を用いて手指筋の筋活動度 を各筋ごとに推定するため，前腕の円柱状導電体モデ ルを作成し，有限要素解析により橈尺骨を含む前腕内 における筋電位の伝導特性を明らかにした。 また，筋 活動部位の位置による表面筋電位の変化を明らかにし た. 得られた伝導特性と表面筋電位分布を用いて筋活 動部位を逆推定し，橈尺骨により生ずる推定位置との 差を比較した。

\section{2. 前腕導電体モデルの構築}

$2 \cdot 1$ 前腕モデルの幾何形状 $90^{\circ}$ 回外位における左 前腕部について，橈尺骨を有するモデルと筋のみのモ デルの 2 種類を作成した（図 2）。前腕部の形状は円 柱状とし, 半径 $R_{A}=40 \mathrm{~mm}$, 長さ $L_{A}=300 \mathrm{~mm}$ とした. 全体座標系は図 2 に示すようにモデル中心を原点とし,
モデルの中心軸近位方向を $z$ 軸, 背側を $y$ 軸, 外側を $x$ 軸, 周方向角度を $y$ 軸を基準とする $\mathrm{z}$ 軸まわり角度 $\theta$ と した. 橈尺骨は半径 $R_{B}=10 \mathrm{~mm}$ の円柱状で前腕モデル と同一長さとし， $z$ 軸と橈尺骨の各中心軸が平行とな るように配置した，橈尺骨はその中心を $z$ 軸から半径 $R_{B C}=23 \mathrm{~mm}$ の位置に配置した。このとき両骨は $y z$ 平 面に対して対称で，両骨の中心と前腕モデルの中心の なす角 $\theta_{B}=120$ ○となようにした。

$2 \cdot 2$ 支配方程式 モデル中の任意の座標における 導電率ベクトルを $\sigma[\mathrm{S} / \mathrm{m}]$, 誘電率ベクトルを $\varepsilon[\mathrm{F} / \mathrm{m}]$, 時刻 $t[\mathrm{~s}]$ とすると, モデル内部の電位 $V[\mathrm{~V}]$ は Maxwell 方程式と電荷保存則より導かれる次の式に従う。

$$
\nabla \cdot\left[\left(\varepsilon \frac{\partial}{\partial t}+\sigma\right) \nabla V\right]=0
$$

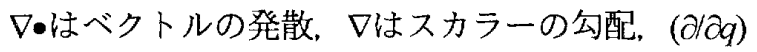
は変数 $q$ に対する偏微分を表す。演算子による指示の ないベクトル同士の積は, ベクトルの要素ごとの積を 表す.

筋と骨はそれぞれ異方性の導電率 $\sigma_{M}$ と $\sigma_{B}$ を有する. 前腕は複数の筋で構成されるが, 本モデルでは, (1)各 筋の筋線維力向が同一，(2)筋を仕切る筋膜は十分薄く 電気的特性に影響しない，(3)各筋の電気的特性值に違 いがない，という 3 つの仮定のもとに，モデル中の筋 組織は一様な異方性の導電率を有するものとした. 半 径方向, 周方向, 軸方向の導電率は表 1 の通りである (18)(19). 空気層は筋に比して十分に小さい等方性の導電 率を有するので， $\sigma_{A}=1.0 \times 10^{-10} \mathrm{~S} / \mathrm{m}$ とした．モデル中 の誘電率 $\boldsymbol{\varepsilon}$ は，影響が十分に小さいものとして無視し た.
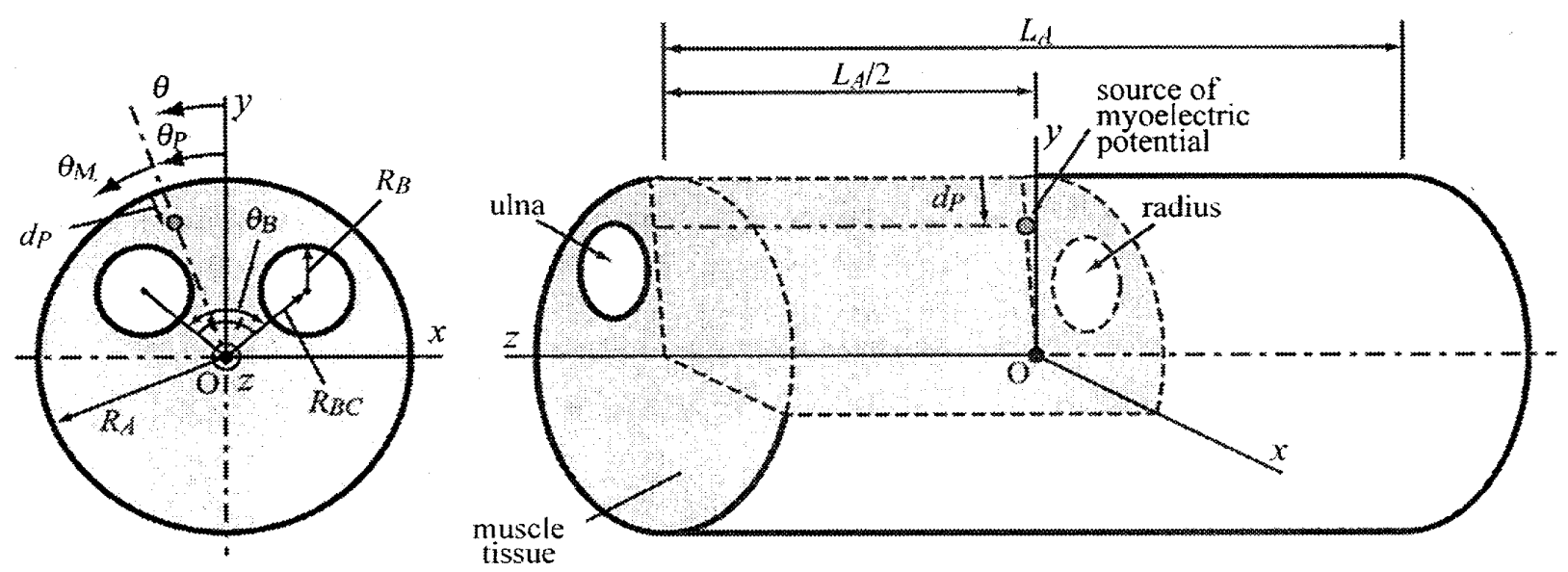

Fig. 2 A conduction model of left forearm. (left: proximal view, right: lateral view) 


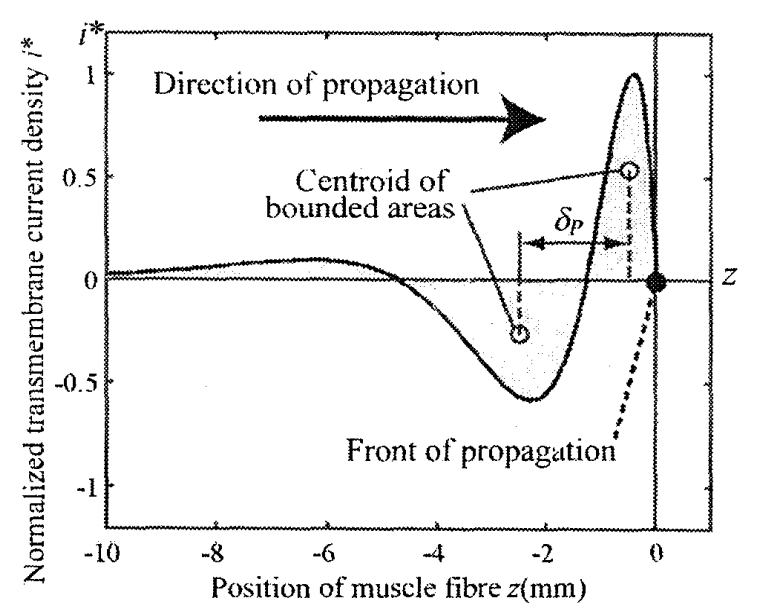

Fig. 3 Simulated normalized transmembrane current density of muscle fibre at $4 \mathrm{~m} / \mathrm{s}$ of the propagation velocity ${ }^{(21)}$

\section{$2 \cdot 3$ 筋電位発生源のモデル化 筋活動電位は，運} 動神経終末からの刺激によって筋線維の筋細胞膜に急 激な電位変化 (脱分極) が生じ，周辺に電流が流れる ことで発生する. 脱分極は筋線維中をほぼ一定の速度 で伝導するが，このときの電位分布状態によって筋線 維中に電流の流入部分と流出部分が生じ，これが筋電 位発生源となる. 本モデルではこの電流の流入・流出 をモデル化するため, 筋電位発生源を電流流入点と流 出点の組，すなわち電流双極子モデルとした.

以下に電流双極子（筋電位発生源）の間隔決定方法 を示す．筋線維の脱分極が速度 $v[\mathrm{~m} / \mathrm{s}]$ で伝播すると， 筋線維外入流出入する電流密度 $i[\mathrm{~A} / \mathrm{m}]$ は，脱分極の伝 播方向を正とする線維方向位置 $z[\mathrm{~m}]$ と速度 $v$, 時刻 $t$ を用いて, 式(2)(3)で表せる(20)(21).

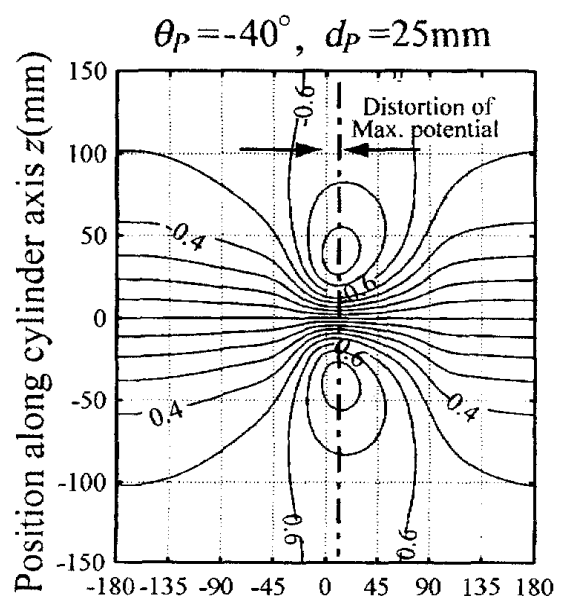

Table 1 Conductivity of a muscle and a bone ${ }^{(19)(20)}$

\begin{tabular}{|c|c|c|}
\hline & Muscle[S/m] & Bone[S/m] \\
\hline Radial & 0.148 & $4.65 \times 10^{-3}$ \\
\hline Circumferential & 0.148 & $6.33 \times 10^{-3}$ \\
\hline Axial & 0.446 & $66.7 \times 10^{-2}$ \\
\hline
\end{tabular}

$$
\begin{aligned}
& i=\left\{\begin{array}{cc}
C \bar{z}\left(6-6 \bar{z}+\bar{z}^{2}\right) k^{-\bar{z}} & (\bar{z} \geq 0) \\
0 & (\bar{z}<0)
\end{array}\right. \\
& \bar{z}=v t-z
\end{aligned}
$$

ここで C は筋線維の断面積と, 線維方向および法線方 向の筋の導電率から決まる定数である. 図 3 は， $v=4 \mathrm{~m} / \mathrm{s}, t=0$ のときの式(2)について, 横軸 $z$, 縦軸 $i^{*}$ （iの最大值で正規化）として表した。このとき， $z=0$ は脱分極の伝播の先端であり，その後方 $(z<0)$ は脱分極 による電位変化の途中にある. 図 3 に示すように，筋 線維の電流密度 $i^{*}$ 注位置によって符号が異なり, $i^{*}=0$ の軸を挟んで $3 つ の$ 領域が描かれる. $z=-3-\sqrt{3}$ 以下

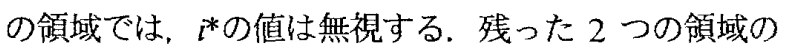
図心位置を電流双極子の両極とし，2 点の間隔 $\delta_{p}=2.1 \mathrm{~mm}$ を双極子間隔とした。

この電流双極子（筋電位発生源）を，図 2 に示すよ うにモデルの中央で周方向角度 $\theta=\theta_{p}$ ， 円柱表面からの 梁さ $d_{P}$ の位置に配置した. 電流双極子の向きは $z$ 軸と 平行とし, 電流強度は基準化のため $1 \mathrm{~mA}$ とした。

\section{$2 \cdot 4$ 有限要素解析 筋電位分布の解析には，有限} 要素解析ソフト ANSYS MultiPhysics Ver.10を使用した. モデル中の要素は3 次元四面体要素とした，要素サイ ズは, 電流双極子近傍を $0.1 \mathrm{~mm}$ とし, 電流双極子直上 の円柱表面の近傍は $2 \mathrm{~mm}$ ，それ以外は $6 \mathrm{~mm}$ とした。

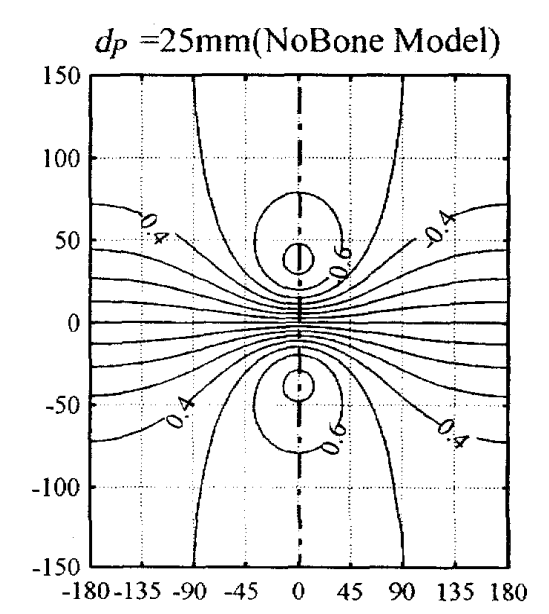

Angle around cylinder axis based on the source position $\theta_{M}(\mathrm{deg})$

Fig. 4 The surface potential distribution maps (Left: $\theta_{p}=-40 \mathrm{deg}$, right: No-bone model). Both of the source depth $d_{l}$, is $25 \mathrm{~mm}$, and the unit of the potential is " $\mu \mathrm{V}$ ". Dashed lines in the figure are circumferential position of the peak of surface potential distribution. 
空気層の要素サイズは $8 \mathrm{~mm}$ とした. また, 空気層の外 縁を基準電位 $(0 \mathrm{mV})$ として固定境界条件を与えた.

以上の条件より, 電流双極子の深さ $d_{p}$ を $5 \mathrm{~mm}$ から $40 \mathrm{~mm}$ まで $5 \mathrm{~mm}$ 刻みで, $z$ 軸回り角度 $\theta_{P}$ を $0^{\circ}$ から $-90^{\circ}$ まで 10 刻みで変化させて解析した。

2 -5 表面筋電位分布 解析により, 円柱の側面に 表面箭電位分布 $V=V(\theta, z)$ が得られた，図 4 では，得 られた表面筋電位分布について骨による分布の歪みを 明瞭に図示するため, 角度 $\theta$ を筋電位発生源の位置を 基準とした角度 $\theta_{M}\left(\theta_{M}=\theta-\theta_{p}\right)$ で置き換え（図 2）, $V=V\left(\theta_{M}, z\right)$ として表した，筋のみのモデルにおける表 面笳電位分布（図 4 右）では，等電位線が $z$ 軸方向を 長軸とする楕円状に広がり， $\theta_{M}=0$ すなわち筋電位発 生源直上の表面には正負 2 点の極值（ピーク電位）が 出現した. ピーク電位の大きさは筋電位発生源の深さ $d_{P}$ の 1.67 乗に反比例して減少した. Roeleveld らが行っ た上腕二頭筋の筋電位減衰度の計測実験によれば(3), 陰性ピーク電位の減衰乗数は $1.60 \pm 0.13$ であり本計算 結果と近いことから，本モデルの妥当性を示す結果を 得た。

一方，橈尺骨を有するモデル (図 4 左， $d_{P}=25 \mathrm{~mm}$, $\theta_{p}=-40^{\circ}$ ) では，ピーク電位点の位置（図 4 左の一点 鎖線部分）が $\theta_{M}=0$ の軸上から周方向に $11^{\circ}$, 近傍の骨 の表面から遠ざかる方向へずれる結果となった.この ずれは，前腕モデルを用いて筋活動部位を推定する場 合に，筋のみの簡易モデルを用いると大きな誤差が生 じることを示している，図 5 はピーク電位点の周方向 のずれと，筋電位発生源深さ $d_{P}$ および $\mathrm{z}$ 軸回り角度 $\theta_{P}$ の関係を表したものである．図中の「*」は筋電位発生 源が骨近傍 $5 \mathrm{~mm}$ 以内にあるときのピーク電位点位置 であること表し，「十」筋電位発生源が直上表面から

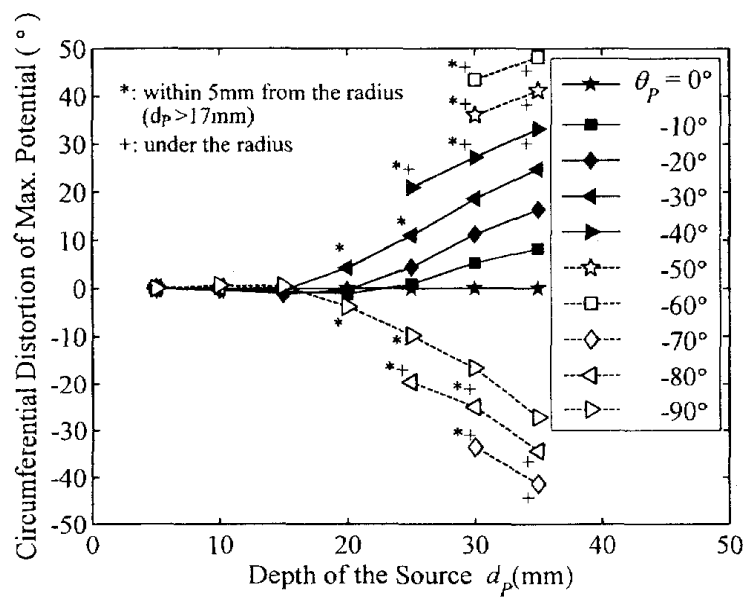

Fig. 5 The circumferential distortion of maximal potential position caused by the bones. The marker "*" in the figure means the source is within $5 \mathrm{~mm}$ from the radius (the source depth $d_{p}>17 \mathrm{~mm}$ ), and "+" means the source is under the radius.
見て橈尺骨の裹側にあるときを表している。図からわ かるように，筋電位発生源深さが橈尺骨の中心付近の 深さ $(17 \mathrm{~mm})$ 以深にあって骨近傍に位置しているか，ま たは筋電位発生源が橈尺骨の裏側にあるときに，ピ一 ク電位点が骨表面から離れる万向へ大きくずれる結果 となった。

\section{3. 筋電位発生源の位置推定}

3・1 表面筋電位 RMS 值の減衰度 表面筋電位分 布 $V$ は静止した筋電位発生源により得られたものだが, 実際は脱分極が筋線維中を伝播することで筋電位発生 源も移動するため，当然表面筋電位分布も移動する.

また，実際の表面筋電位は皮膚表面上の 2 点に貼り付 けた電極刘の電位差を計測し，そのRMS 值(Root Mean Square, 2 乗平均平方根) を算出するのが一般的である. しかし，(1)筋電位発生源からの入力電流は瞬時にモデ ル全体に伝わること（筋の静電容量成分によるロ一パ スフィル夕効果の無視），(2)筋電位発生源から十分離 れた点の電界強度が 0 に近いこと，(3)筋電位発生源が ほぼ一定速度で移動すること（脱分極が一定速度で筋 線維中を伝播する）の3点を考慮すると，モデル表面 の電極対を筋電位発生源の移動速度で「スライド」す ることで筋電位分布の移動と置き換えて表現できるこ とから，静止した分布から近似的に筋線維の活動 1 パ ルスあたりの表面筋電位 RMS 值が得られる.

以下にその方法を述べる. 静止した筋電位発生源に よる表面筋電位分布 $V(\theta, z)$ に刘して, $z$ 方向に幅 $\Delta z$ の 中央差分 $\Delta V$ をとる. $\Delta z$ が電極間隔（inter-electrode distance, IED）， $\Delta V$ が電極間の電位差に相当する.

$$
\Delta V(\theta, z)=V(\theta, z+\Delta z / 2)-V(\theta, z-\Delta z / 2)(4)
$$

このとき，值が算出されていない部分（モデル両端 の外）は電位差が小さいものとして $\Delta V=0$ とする。

$z$ 方向のサンプリング間隔 $\zeta=v / q$ （q は時間領域に おけるサンプリングレート $(\mathrm{Hz})$ ）を適当に決め，各サ ンプリング点における中央差分 $\Delta V_{k}$ を 2 乗して $z$ 方向に ついて加算平均すると，筋線維の活動 1 パルスあたり の表面筋電位 RMS 值分布 $V_{\mathrm{ms}}(\theta)$ が得られる.ここで は, $\zeta=1 \mathrm{~mm}$ とした.

$$
V_{\mathrm{rms}}(\theta)=\left(\frac{1}{N} \sum_{k} \Delta V_{k}^{2}\right)^{1 / 2}
$$

ここで, $k$ は整数， $N$ は自然数で，それぞれ $k=-L_{A} / 2 \zeta \ldots$ $-L_{A} / 2 \zeta, N=\left(L_{A} / 2 \zeta\right)+1$ である.

以上の方法により，筋のみのモデルの全周に電極間 隔 $\Delta z$ の電極対を周方向角度 $\theta=0$ から $350^{\circ}$ まで $10^{\circ}$ おき に 36 対配置したと仮定して，各電極対の筋電位 RMS 


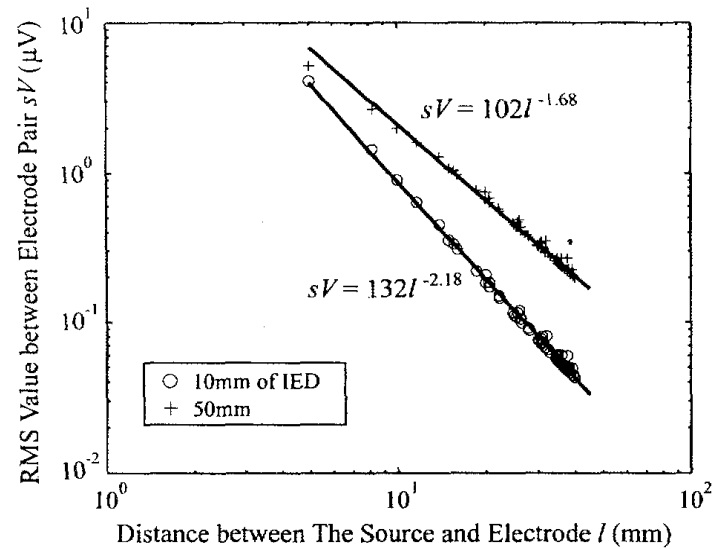

Fig. 6 The attenuances of RMS value caused by the difference of inter-electrode distance (IED)

值 $V_{\mathrm{rms}}$ と，電極対から筋電位発生源までの半径方向距 離 $l$ を算出した. 筋電位発生源の位置は $\theta_{p}=0^{\circ}$ とし, 深 さ $d_{P}=5,10, \ldots, 40 \mathrm{~mm}$ それぞれについて $V_{\mathrm{ms}}$ とlを求め た. 図 6 は, $\Delta z$ を $10 \mathrm{~mm}$ と $50 \mathrm{~mm}$ としたときの $V_{\mathrm{ms}}$ とlをプロットしたものである. 図から明らかなよう に, RMS 值は筋電位発生源が電極から離れるに従い急 速に減衰し，その減衰度は電極間隔 $\Delta$ により異なった。 この減衰は減衰乗数 $b$ と, 筋活動の強度によって決ま

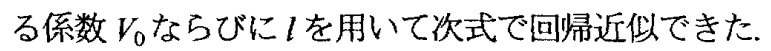

$$
V_{\mathrm{rms}}(\theta)=V_{0} l\left(\theta, d_{P}\right)^{b}
$$

式(6)の $b$ は $\sharp=10 \mathrm{~mm}$ のとき-2.18,50mm のとき -1.68 となった。この回帰式を用いて, $\Delta z$ と $V_{0}, b$ の 関係を表したものが図 7 である. 減衰乗数 $b$ は, 電極 間隔 $\Delta$ が広くなるほど大きくなった.この結果は， Roelveld らが行った実験と傾向がほぼ一致した ${ }^{(3)}$ ここの 結果を応用すれば，電極間距離による減衰乗数の差を 利用し， 2 対の異なる間隔の電極を用いて浅部と深部 の筋活動を分離して計測できる.

$3 \cdot 2$ 筋電位発生源の位置推定 式(6)による筋電位 減衰度の回帰近似の結果を利用して, 橈尺骨を有する モデルの RMS 値分布 $V_{\mathrm{ms}}$ から筋電位発生源の位置推 定を試みた。

以下に方法を示す．角度 $\theta_{i}$ にある電極対 $i(i=1 . \mathrm{n})$ か ら得られた RMS 值 $V_{\mathrm{ms} i}=V_{\mathrm{ms}}\left(\theta_{i}\right)$ は既知とする。式(6) の右辺を末知の筋電位発生源位置 $x_{p}=\left(x_{P}, y_{P}\right)$ と強度 $V_{0}$ を变数とする回帰推定関数 $f_{i}$ と置き換える.

$$
\begin{aligned}
& f_{i}\left(x_{p}, y_{p}, V_{0}\right)=V_{0} l_{i}^{b} \\
& l_{i}=l\left(\theta_{i}, x_{p}, y_{p}\right) \\
& \quad=\sqrt{\left(x_{p}-R_{A} \cos \theta_{i}\right)^{2}+\left(y_{p}-R_{A} \sin \theta_{i}\right)^{2}}
\end{aligned}
$$

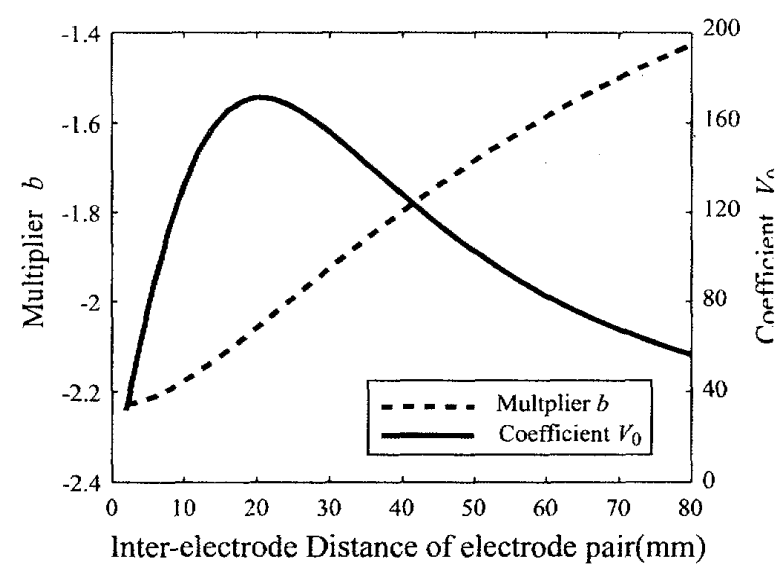

Fig. 7 The attenuance multiplier of RMS caused by the difference of IED

式(7)の $b$ は，式(6)により，筋のみの解析モデルから 得られた減衰乗数である. 式(6)(7)を用いて次の RMS 值推定誤差 $e_{i}$ が得られる.

$$
e_{i}=V_{\mathrm{rms} i}-f_{i}
$$

式(7)を $x_{p}, y_{p}, V_{0}$ について 1 次の Taylor 展開を行い 式(9)に代入すると次式を得る.

$$
\boldsymbol{e}=\left[\begin{array}{ccc}
\frac{\partial f_{1}}{\partial x_{P}} & \frac{\partial f_{1}}{\partial y_{P}} & \frac{\partial f_{1}}{\partial V_{0}} \\
: & : & :
\end{array}\right]\left[\begin{array}{c}
\Delta x_{P} \\
\Delta y_{P} \\
\Delta V_{0}
\end{array}\right]=\boldsymbol{D} \Delta \boldsymbol{x}
$$

ここで, $e=\left[e_{1} \ldots e_{\mathrm{n}}\right]^{\mathrm{T}}$ である. 式(10)より，e のノル 厶を最小にする方向を持つベクトル $\boldsymbol{A x}$ は，Dのム一 ア・ペンローズ逆行列 $\boldsymbol{D}^{+}$を用いて次のように表される.

$$
\Delta x=D^{+} e=\left(D^{\mathrm{T}} D\right)^{-1} D^{\mathrm{T}} e
$$

このようにして得られた $\Delta \boldsymbol{x}$ に小さな定数 $k$ をかけ た $k \Delta \boldsymbol{x}$ を $\left[\begin{array}{lll}x_{P} & y_{P} & V_{0}\end{array}\right]^{\mathrm{T}}$ に加算して収束計算を繰り返し， 誤差 $e$ のノルムが最小となる点を筋電位発生源の推定 点 $\left(x_{P}, y_{P}\right)$ とした.

以上の方法により，仮想電極対 $i$ がモデル全周に $\theta=0^{\circ}$ から $10^{\circ}$ 間隔で $\mathrm{n}=36$ 対配置されたと仮定した場 合の筋電位発生源の位置推定結果を図 8 に示す。笳電 位発生源の位置が図中のある 1 点（黒丸）にある時の) 筋電位分布を用いて, その位置を逆推定した結果が図 中の白丸である. 図 8 には，これらの逆推定を筋電位 発生源 1 点ごとに別々に算出したものをまとめて記載 し、筋電位発生源（黒丸）に対応する推定点（白丸） をそれぞれ直線で結んだ. 推定誤差は筋電位発生源の 位置が橈尺骨近傍のときと，直上表面から見て橈尺骨 の裹側に位置するときに大きくなった。電極間 

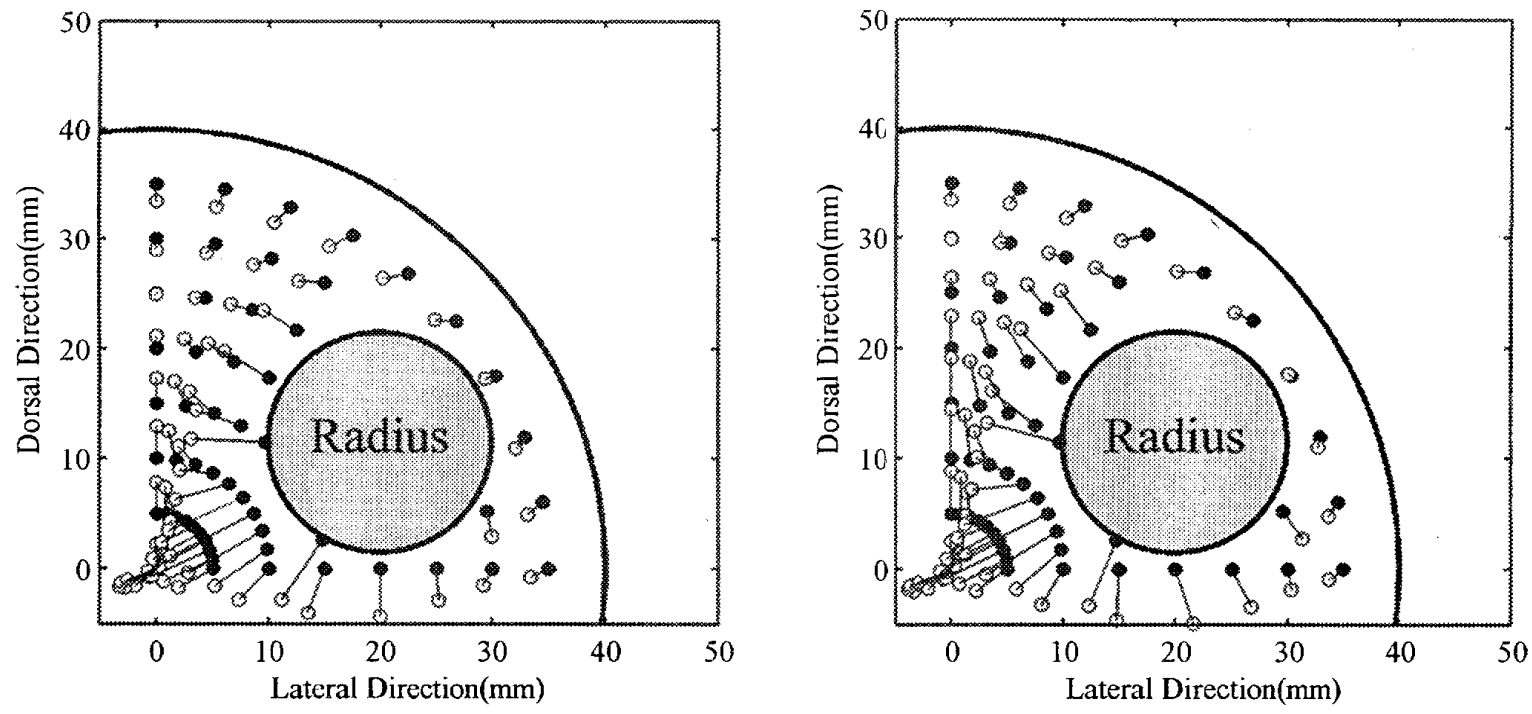

Fig. 8 Estimation of source position.

(left: $10 \mathrm{~mm}$ of IED, right: $50 \mathrm{~mm}, \bigcirc$ : estimated position of the source, $\mathrm{O}$ true position of the source)

隔 $\Delta z=10 \mathrm{~mm}$ のときの回㷌近似結果を用いた場合は最 大䛊差 $8.4 \mathrm{~mm}, 50 \mathrm{~mm}$ の場合は $8.2 \mathrm{~mm}$ となった．最大 誤差に大きな違いはないが, $\Delta z=10 \mathrm{~mm}$ のほうが推定 位置が深くなる傾向にあった。

\section{4. 考察}

4・1 電槡間隔とダイナミックレンジ 解析結果か 万，表面筋電計による筋電位測定における RMS 值の 減衰は電極対と筋電位発生源間の距離 $l$ のよそ2.2〜 1.7 乗に反比例することがわかった. これを $d_{P}=5 \mathrm{~mm}$ と 40mm ( $d_{p}$ の最浅深さと最深深さ) の RMS 值比で比 較すると，電極間隔 $\Delta z=10 \mathrm{~mm}$ で約 $(40 / 5)^{2.18}=93$ 倍

(6.5bit, 39dB)， $50 \mathrm{~mm}$ で $(40 / 5)^{1.68}=33$ 倍（5.0bit, 30dB）となる．つまり，電極間隔が狭いと急激に減衰 し、広いと緩やかになる。この性質を利用すれば，間 隔の狭い電極対と公い電極対の組を前腕の円周上に多 数配置することで，狭い電極対で浅層筋の活動を識別 し，広い電極対で深層筋の活動を捉えることができる. また，狭い電極対の計測值を用いて広い電極対の筋電 位加浅層筋のクロストークを除去し，深層筋の筋電 位推定に用いることができる.

一方，周方向の電極の配置間隔について，各筋ごと に筋電位を分離するには，隣接する筋の近接度と表面 筋電位分布の空間周波数を考虑する必要がある. 本推 定法において重要となるのは, RMS 值分布計測の空間 分解能すなわち電極対の周方向間隔である. RMS 值分 布が鋭くとがった形状 (浅層の筋活動による)のとき， 分布の波形を十分な分解能で計測できれば全ての深さ で位置推定が可能である. $d_{P}=5 \mathrm{~mm}$ における表面筋電 位分布の極大值波形の幅はおよそ $60^{\circ}$ であり、これを 5 分割する程度の分解能があればRMS 値分布形状を再
現できることから，周方向電極間隔が $60 /(5-1)=15^{\circ}$ あ れば，本推定法には十分である，つまり，円周上に 360/15=24 対の電極があれば, 前腕諸筋の位置と強度 の推定が可能となる.

4.2 笳電位の減衰度 Roeleveld らは, 電極対の電 位差の振幅と時間積分值で距離に対する筋電位の減衰 度を測定している(3). 本解析についてこれらの数值を 比較した結果、減衰傾向は一致した。しかし，減衰乗 数は本解析のほうが 0.5 程度小さくなった.これは, 解析に用いた筋の導電率の差や，皮膚や脂肪によるフ ィル夕效果による影響と推察される. 導電率の異方性 が異なれば表面筋電位分布が軸方向に伸縮し(2)，電極 間隔に対する減衰乗数が異なる結果となる.

また，脂肪は筋に比して低導電率，高誘電率であ り，筋電位伝導時にローパスフィルタ効果を有す ることがわかっている(21). 今後の検討においては これらの点のほか，ノイズやドリフトなどの影響 などを考慮する必要がある。計测装置の限界から これを考察すると, 計測器の A/D コンバータに対 して最弱な筋電位（最深層）の強度を十分な精度 で計测するには 5bit 程度の分解能が必要である。

次に，筋電位の基線ドリフトや筋電位のオ一バレンジを防ぐためには，計測レンジに $3 b i t$ 程度の マージンが必要である。さらに，同時に計測する 筋電位の最大最小比（最浅部と最深部の筋電位強 度の比） $\mathrm{Q}$ と微小ノイズのマージン $\mathrm{N}$ を考慮する 必要がある。これらの関係は，(A/D 分解能）= (計測レ・ジマージン) $+($ ノイズマージン $)+\mathrm{N}+\mathrm{Q}$, と表せる。計測器の A/D コンバータの分解能が-.. 般に用いられている16bit とすると，Q=8－Nとな 
り，ノイズマージンを 2 ないし 3 bit とすれば, $\mathrm{Q}=5$ ないし 6bit となる。このとき， $d_{P}=30 \mathrm{~mm}$ におけ る Q 㤬 $\Delta z=10 \mathrm{~mm}$ における減衰乗数を用いて計算 すると $(30 / 5)^{2.18}=50 \quad$ (5.6bit),$\Delta z=50 \mathrm{~mm}$ で $(30 / 5)^{1.68}=20$ (4.3bit)となる.これらの点を考慮する と，実際の計測では減衰度から見て概就測限界 $30 \mathrm{~mm}$ 以内にとどまる。

\section{4・3 橈尺骨による筋電位発生源の推定誤差 筋電}

位発生源が橈尺骨近傍にあるとき，表面筋電位分布は

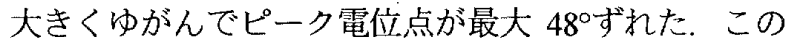
ときの筋電位発生源位置の推定䛊差は $8 \mathrm{~mm}$ 以上とな り，別の筋の活動による筋電位と誤推定する可能性が ある.これを防ぐ方法としては，本解析結果を忘用し て橈尺骨による表面筋電位分布の歪みを補正する方法 が考えられる，電極と筋の概ねの位圆をあらかじめ入 力し、計測結果に本解析結果による補正を適用すれば, 推定精度を向上できる。

さらに，計測前に行うキャリブレーションにより， 人体内部のパラメータの個人差（脂肪，皮膚抵执など の要因による）と本解析結果を照合し，筋活動部位の 推定位置や筋活動度を補正する方法が考えられる. 特 定の筋のみの活動による表面筋電位分布計测や，微弱 電流の通電による内部インピーダンス測定などにより 推定位置の補正を行えば，より精度の高い推定結果が 得られる.

また，本手法は単一の筋の位置及び活動度推定にと どまるが, 実用的には複数筋の同時推定が必要となる. しかし，本手法は実際の表面筋電位がガウス分布に近 い挙動を示すことを利用して，筋線維ごとの RMS 值 をその 2 乗值の加減算により集約することが容易なた め, 少ない計算量で最適化手法により各筋の筋活動位 置と強度を個別に推定可能である. 先に述べた通り， 間隔の狭い電極対と広い電極対を用いて測定すれば浅 層筋のクロストークを除去しつつ深層筋の箭電位を得 られることから，最適化手法との併用により深層筋の 筋活動も推定可能となる.

以上により，表面筋電計測による複数筋の活動度の 同時推定の可能性が得られた。

\section{5. 哧 論}

前腕を筋と橈尺骨の冈柱状導電体としてモデル化 し，筋電位発生源を電流双極子モデルに置き換えて有 限要素法を用いて解析し, 表面筋電位分布を算出した。 得られた分布から筋電位発生源の深さに対する表面筋 電位の減衰乗数を求め，これを用いて筋電位発生源の 位置を逆推定し, その推定誤差を比較した. その結果, 減哀乗数は電極間隔で異なり，間隔が広いほど減衰は 緩やかとなった，橈尺骨の位置によって表面筋電位分 布のピーク電位点は大きく䄳み, 最大 $48^{\circ}$ の周方向悞
差が発生した，筋電位発生源の推定䛊差は骨近傍で大 きくなり，最大 $8.4 \mathrm{~mm}$ となった。

今後は検証のため，表面筋電位の多点同時計測によ る複数筋の筋活動度推定実験を行う予定である.

\section{謝辞}

本研究は, 独立行政法人科学技術振興機構の地域イ ノベーション創出総合支援事業・平成 20 年度シーズ発 掘試験Aの研究助成金を受けた。ここに記して謝意を 表す。

\section{文献}

(1) Nakamura, R. and Saitoh, H., Kiso Undo-gaku, (1976), p185, Ishiyaku Shuppan.

(2) Roeleveld, K. et al., The Motor Unit Potential Distribution over the Skin Surface and Its Use in Estimating the Motor Unit Location, Acta Phisiologica Scandinavica, Vol. 161 (1997), pp. 465-472.

(3) Roeleveld, K. et al., Motor Unit Potential Contribution to Surface Electromyography, Acta Phisiologica Scandinavica, Vol. 160 (1997), pp. 175-183.

(4) Roeleveld, K. et al., Motor Unit Size Estimation: Confrontation of Macro EMG and Surface EMG, Electroencephalography and Clinical Neurophysiology, Vol. 105 (1997), pp. 181-188.

(5) Roeleveld, K. et al., Motor Unit Size Estimation of Enlarged Motor Units with Surface EMG, Muscle Nerve, Vol. 21 (1998), pp. 878-886.

(6) Kleine, B. U. et al, Surface EMG Mapping of the Human Trapezius Muscle: the Topography of Monopolar and Bipolar Surface EMG Amplitude and Spectrum Parameters at Varied Forces and in Fatigue, Clinical Neurophysiology, Vol. 111, No. 4 (2000), pp. 686-693.

(7) Kleine, B. U. et al, Using Two-dimensional Spatial Information in Decomposition of Surface EMG Signals, Journal of Electromyography and Kinesiology, Vol. 17, No. 5 (2007), pp. 535-548.

(8) van Elswijk, G., Kleine, B.U. et al., Muscle imaging: Mapping responses to transcranial magnetic stimulation with high-density surface electromyography, Cortex, Vol. 44, No. 5 (2008), pp. 609-616.

(9) Maekawa S. et al., MU Decomposition from Multi-Channel Surface EMG Signals Using Blind Deconbolution, Transactions of the Institute of Electronics, Information and Communication Engineers, Series D, Vol. J88-D-II, No.9 (2005), pp. 1963-1970.

(10) Matsuura, T., et al., 3D Position Estimation of the Motor Unit form Surface EMG, Technical Report of the Institute of Electronics, Information and Communication Engineers, MBE2004-112 (2005), pp. $1-4$.

(11) Saitoh, K. et al., Validity of the Image Method in Surface Myoelectricity Order and Inverse Analysis: Viewpoint of the Effect of Boundary, Transactions of the Society of Biomechanisms Japan, Vol. 21, No. 2 (1997), pp. 92-97.

(12) Saitoh, K. et al., Current Sources Estimated by Inverse Analysis of Surface EMG, Biomechanisms, Vol. 13 (1997), pp. 89-98. 
(13) Saitoh, K. et al., Muscular Unit Size and Fiber Density Deduced from Simulation of Inverse Analysis of Surface Electromyograms, Japanese Journal of Physical Fitness and Sports Medicine, Vol. 53, No. 4 (2004), pp. 391-402.

(14) Saitoh, K. et al., Validity of Location of Muscular Units Estimated through Inverse Analysis of Surface Electromyograms, Japanese Journal of Physical Fitness and Sports Medicine, Vol. 53, No.5 (2004), pp. 549-557.

(15) Vigouroux, L. et al., Using EMG Data to Constrain Optimization Procedure Improves Finger Tendon Tension Estimations During Static Fingertip Force Production, Journal of Biomechanics, Vol. 40, No. 13 (2007), pp. 2846-2856.

(16) Vigouroux, L. et al., Estimation of Finger Muscle Tendon Tensions and Pulley Forces During Specific Sport-climbing Grip Techniques, Journal of Biomechanics, Vol. 39, No. 14 (2006), pp. 2583-2592.

(17) Tadano, S. and Fukada, K., Numeral Analysis of Musculotendinous Forced and Joint Reaction Forces during Motion of Index Finger, Transactions of the
Japan Society of Mechanical Engineers, Series A, Vol. 67, No. 653 (2001), pp. 168-174.

(18) Burger, H. C. and Van Dongen, R., Specific Electric Resistance of Body Tissues. Physics in Medicine and Biology, Vol. 5, No.4 (1961), pp. 431-447.

(19) Saha, S. and Williams, P. A., Electric and Dielectric Properties of Wet Human Cortical Bone as a Function of Frequency, IEEE Transactions on Biomedical Engineering, Vol. 39, No. 12 (1992), pp. 1298-1304.

(20) Stoykov, N. S. et al, Frequency- and Time-Domain FEM Models of EMG: Capacitive Effects and Aspects of Dispersion, IEEE Transactions on Biomedical Engineering, Vol. 49, No. 8 (2002), pp. 763-772.

(21) Rosenfalck, P., Intra- and Extracellular Potential Fields of Active Nerve and Muscle Fibres, Acta Phisiologica Scandinavica, Supplementum 321 (1969).

(22) Nakajima, Y. et al., A Finite-Element Analysis of Volume Conduction of EMG Signal on Deep Muscles in a Forearm, The 20th Bioengineering Conference, annual meeting of BE D/JSME, (2008), pp. 377-378. 